\title{
による慢性黒色皮膚炎
}

\author{
濱 田稔 夫*, 堀口俊 一**
}

\section{A CASE OF CHRONIC MELANODERMATITIS DUE TO THE RUBBER PEEPHOLE OF A SHIP-RADAR-SCOPE}

\author{
Toshio HAMADA $\dagger$ and Shun'ichi HoRIGUCHI††
}

\begin{abstract}
A patient with peculiar pigmentation on the face and hands was examined and it was clarified that the nature of pigmentation was chronic melanodermatitis due to the rubber covering with which he was usually in contact to look into the radar in his working ferry boat.

The patient is a 40-year-old Japanese with no specific family history, working as captain of a ferry boat in the Setonaikai-line. He noticed reticular brownish black pigmentation with itchy dark reddish tone on periorbital regions, extending particularly to forehead, zygomatic regions, cheeks and nose, and the lateral margin and the back of hands about 6 months ago. These symptoms gradually increased. Histopathological examination of the left cheek with reticular pigmetation showed perivascular lymphoid infiltration and numerous melanophages in the upper dermis, and postinflammatory pigmentation was suggested. He used to look into the radar during the operation of his working ferry boat and the contact region of the rubber covering on the peephole of the radar-scope almost coincided with the peculiar pigmentation of the face. Patch tests with this rubber product and paraphenylenediamine, one of rubber antioxidants, showed positive results, but with mercaptobenzothiazole and tetramethylthiuram disulfide, accelerators producing most cases of rubber dermatitis, they were negative. As substances with similar structural formulas of paraphenylenediamine in rubber antioxidants may show cross-sensitized reactions, it was suggested that paraphenylenediamine or substituted paraphenylenediamine was contact allergens of this melanodermatitis. When the contact allergens, not so strong, continue to contact for a long time, liquefaction degeneration of basal cells occurs, then melanin granules, dropping to the dermis, are present as melanophages in the upper dermis. As such, the pigmentation seems to gradually appear. The literature reported hitherto in Japan on the chronic melanodermatitis due to rubber products is reviewed herewith.
\end{abstract}

\section{I.は じめに}

コムによる職業性の接触皮庯炎の多くはアレルギー性 で, ゴム加工に使用されている加硫促進剤や酸化防止刜 に原因が求められている って発生する皮庙炎は職業性, 非職業性を問わず, 臨床

* 大阪市立大学医学部皮庙科学教室

** 大阪市立大学医学部衛生学公衆衛生学教室 昭和52年 3 月 14 日受付

† Department of Dermatology, Osaka City University Medical School

t† Department of Preventive Medicine and Public Health, Osaka City University Medical School Received for publication, March 14, 1977
症状の部位やパターンに特改的なものが多い. われわれ は顔面および手に瘭痒を伴った特異な色素沈着をきたし た症例を経験し, 精査の結果, 職業的に常時接触してい る船船レーダーのぞき口のゴムによる慢性黒色皮席炎と 判明した.ここに本例について報告するととすに，黒色 皮成炎の成因, コムム皮㖇炎の現状についても文献的に若 干の考察を加えた。

\section{II. 症例}

患者 : 40歳, 男. 職業 : 瀬戸内海航路フェリーボート 船長. 家族歴および既往歴：特記すべきことはない。

現病歴：約 6 か月前より顔面および手に軽度の発赤と 㾇痒に気付いていた。しかし 4 か月前より漸次, 顔面の 
とくに眼窝部周囲に黒褐色の色素沈着をきたすようにな る. 昭和48年 4 月 21 日大阪市立大学医学部附属病院皮店 科外来を受診し，検査のため入院した.

現 症 : 顔面では左右対称性に前額, 煩骨部, 㛲部, 其背部にかけて眼窝部周囲を带状に軽度の瘦痒ととすに 暗赤調を伴った黒蝎色の網状色素沈着が比較的明瞭に認 められる (Fig. 1，2). また両手背より外绿にかけてる, 面面ほと影著ではないが，同様の色来沈着が認められる (Fig. 3). とすに軽度の瘦痒を伴っている.

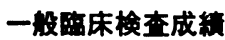

赤血球数 $489 \times 10^{4}, \mathrm{Hb} 15.0 \mathrm{~g} / \mathrm{dl}$, ヘマトクリット 值 $45.7 \%$, 白血球数 9,000 , 白血球像 : 好塩球 0 , 好酸 球 0 , 好中球, 桿状型 $8 \%$, 分葉型 $32 \%$, リンパ球 56 $\%$, 単球 $2 \%$.

LE test (一), 梅毒血清反応 : 緒方法 (一), TPHA (一), 血沈 : 1 時間値 $4 \mathrm{~mm}, 2$ 時間值 $12 \mathrm{~mm}$.

ASLO 100 Todd $\mathrm{u}$ 以下, CRP(-), RA(-).

GOT $41 \mathrm{u}$, GPT $48 \mathrm{u}$, 血清総ビリルビン $0.9 \mathrm{mg} / \mathrm{dl}$, チモール $3.6 \mathrm{u}$, クンケル $9.0 \mathrm{u}$.

血清総タンパク $7.2 \mathrm{~g} / \mathrm{dl}$, 血清タンパク分画: Albu$\min 63.6 \%, \alpha_{1}$-globulin $3.2 \%, \alpha_{2}$-glb. $7.9 \%, \beta$-glb. 9.3\%,r-glb. $17.4 \%$.

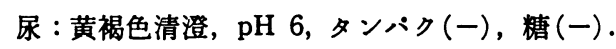

尿中 $17 \mathrm{KS} 6.95 \mathrm{mg} / \mathrm{day}, 17 \mathrm{OHCS} 9.2 \mathrm{mg} / \mathrm{day}$, 血 中コルチゾール $4.0 \mu \mathrm{g} / \mathrm{dl}$.

胸部 X線写真および心龟図: 異常所見を認めない。 病理組織学的所見 : 左頓部の暗赤調を伴った黒褐色の 椆状色素沈着部皮疹の組織検查では, 表皮は扁平でやや 萎樎している. 表皮基底層の排列すほぼ正常で液状変性 の所見はほとんどみられていない，表皮直下には多くの メラニン領食細胞（melanophage）がみられ，また真皮 上層より中層にかけて毛細血管周囲性にリンバ球性小円 形細胞浸潤がかなり珰められる. 真皮の膠原線稚はやや 好塩基性の変性を示している (Fig. 4). 以上の組織像か ら炎症による色素沈着と考えられ, 発生経過, 臨床像か ら柽度の接触皮庙炎が長期間持続している可能性が強く 考えられた。

そこで，以上の所見が職莱起因性か否かを確かめるた めに，患者に詳しく作举態様について質問した。彼は約 2 年間, 同じ船の船長を務めており，運航に祭してしば しばレーダーをのぞく. その時間は 1 日延 30 分位であ る.レーダーののぞきロはコム製品で，顔面に密着する ようになっており (Fig. 5), このゴムの接触する部分に はぼ一致して色素沈着が認められる. 以上のことから， 当陔患者の皮庙障害はゴムによる慢性黒色皮痽炎である
可能性が強く示唆された.

貼布試験：本患者の背部皮㡸に対して, 上記のレーダ 一のぞきロのゴム製品と、 ゴム加硫促進剤である2mercaptobenzothiazole (MBT), tetramethylthiuram disulfide (TMTD), ゴム酸化防止剂の中の代表的な paraphenylenediamine (PPDA) などについて, ゴムは 直接, その他はそれぞれ白色ワセリンに $1 \%$ 溜度含有し たものを閉鎖貼布した. 48時間後に除去して判定すると ともに, 72,96 時間目にす判定を行なった.ささらにゴム 配合剤と直接関連性はないが, 塩化コバルト $\mathrm{CoCl}_{2}$, 重 クロム酸カリウム $\mathrm{K}_{2} \mathrm{Cr}_{2} \mathrm{O}_{7}$, 硫酸第 2 クロム $\mathrm{Cr}_{2}\left(\mathrm{SO}_{4}\right)_{3}$, 硫酸ニッケル $\mathrm{NiSO}_{4} \cdot 6 \mathrm{H}_{2} \mathrm{O}$, 塩化第 2 水銀 $\mathrm{HgCl}_{2}$ など の重金属についても同様の方法で貼布試験を行なった. 結果はゴム, PPDA に陽性を示し, 96 時間目です共に 陽性反応が持続したので，1次刺激によるすのでなく， アレルギー刺激と考えられた (Fig. 6). MBT, TMTD は陰性であった. 重金属では 48 時間後判定は陰性であ った.しかし 72 時間目には, 塩化第 2 水銀は陽性を示 し, 重クロム酸カリウム, すなわち 6 価クロムおよび硫 酸ニッケルでる弱陽性を示した.

貼布試験 48 時間行なったのち, 除去して紫外線照射 を行なら光線貼布試験も併用した. しかし紫外線照射に よってとくに強く反応することはなかった。 また最小紅 斑量 (MED) ठほぼ正常範囲で，それの低下は認められ なかった.

治療および経過 : 船舶運航に際してレーダーをみる必 要のある時には, レーダーのぞきロのゴム製品に接触し ないように厳重に注意させるととるに, 直射日光をでき るだけ避けるよらにさせた。治㞠として顔面および手に コルチコイド含有クリームをらすく塗布させ, vitamin C および glutathione の内服を継続させた。瘦痒は間 あなく消失し, 数か月後には色素沈着す軽快している.

\section{III. 考寮}

職業起因性のゴム皮庙炎にはゴム工場で発生するる の, ゴム製品の保護具を使用して発生するすのなどがあ げられる．ところで，接触皮应炎をきたす可能性のある ゴム製品は多種多様である2．防塵マスクによる皮疦障 害が一時, 本邦において多発した. それらはマスクの皮 府接触部分がゴム製品であったためによるゴム皮后炎 で，小林と雑賀 ${ }^{3)}$ は色秦沈着を伴った 4 症例を報告し， 貼布試験ではゴム製品とともにゴム配合剂中の酸化防止 剤である N-phenyl- $\beta$-naphthylamine によってる強陽 性を示した。自験例はレーダーののぞきロがゴム製品 であり,レーダーを見る時, 顔面皮府をしばしば密着さ 
せる，それをくり返しているらちに，ゴム製品中のある 原因物質によって感作され，そのためにおこったアレル ギー性接触皮庙炎と考兄られる，资症症状はそれはど强 くはなく，むしろ網目状の色素沈着と特異な発生部位が 特徵である．診断確定には貼布試験などとともに作業環 境ならびに作業態様を十分調查する必要性が 痛感され る.

ゴム皮膚炎の主な原因物質はゴム加工に際して配合さ れる加硫促進剤（rubber accelerators）や酸化防止剤 (rubber antioxidants) など，それぞれ多種類にわたる. Fisher ${ }^{1)}$ はとくにゴム皮届炎を発生させやすいものとし $\tau$, 加硫促進㶡では MBT, tetramethylthiuram monosulfide (TS), diphenylguanidine (DPG), hexamethylenetetramine (methenamine), 酸化防止剂では monobenzylether of hydroquinone (MBEH), N-phenyl- $\beta$ naphthylamine, N-isopropyl-N-phenylparaphenylenediamine (IPPDA), 4, 4'-diaminodiphenylmethane を あげている. 今回, われわれの行なった貼布試験はゴム 製品自身とゴム加硫促進剤の代表的な MBT, TMTD, ゴム酸化防止㓮の PPDA および数種の重金属にすぎな い.MBT, TMTD ともに陰性で，ゴム製品自身と PPDA は陽性を示した.

ゴム皮庙炎患者のうち，加硫促進剤による貼布試験で の陽性頻度については，Wilson“は は 109 例のゴム皮庙 炎について dipentamethylenethiuramdisulfide (PTD), TMTD, MBT, zinc diethyldithiocarbamate (ZDC) の 4 種類の加硫促進剂による貼布試験を行ない，PTD の 陽性率 $68 \%$, TMTD 54\%, MBT 47\%, ZDC 24\% を 示し, 斎藤と山蔦 ${ }^{5)}$ はゴム皮庯炎 23 例に加硫促進剤の 貼布試験を行なって DDG 陽性者 7 例, MBT 9 例, TS 5 例，TMTD 4 例であったと報告している。 また Fregert ${ }^{6)}$ はゴム手袋皮庙资患者で MBT の貼布試験陽 性を示した 12 例について, 類似構造式をるつ 10 種の化 学物質による貼布試験を行ない，構造式にベンゼン核と チアゾール環が組み合わさって，しかもチアゾール環の 2 の位置に thiol 基を有し，その水素の置換したものな いししないものが交差過敏性を示すと述へている。

一方, ゴム酸化防止昘に PPDA およびその類似構造 式を示す化学物質がかなり使用されており，Brand ${ }^{72}$ は ゴム皮膚炎患者 11 例に MBT, TMTD, PPDA の貼布 試験を行なったところ，MBT 陽性者 10 例，TMTD 5 例, PPDA 3 例で, 3 種類すべて陽性を示したもの 1 例，MBT と TMTD の 2 種類陽性 3 例，MBT と PPDA の 2 種類陽性 2 例であったと報告している.PPDA はそ れと類似構造式を示す多数の化学物質と交差過敏性を示
すことが知られており，Gaul8) とよれば PPDA 貼布試 験陽性を示した 7 例についてゴム酸化防止剂の 7 種類の amine 物質の貼布試験を行ない, butyraldehyde aniline condensation 2 例, 2, 4-toluene diamine 2 例, 4,4dimethoxydiphenylamine 1 例佁陽性を示した。 Sch $\phi$ nning と Hjorth9) とよれば，新しいゴム酸化防 止剤である 4-isopropylamino-diphenylamine ( $\mathrm{N}$-isopropyl-N-phenylparaphenylenediamine, IPPDA) が貼 布試験で高い陽性率を示し，これはまた PPDA 類似構 造式を有する物質にも過敏性を示した。そして IPPDA と hair dye (白髮染) の $p$-amino-diphenylamine (PADP) との間に高い頻度で交差反応がみられたと述へている。 Jordan ${ }^{10)}$ はコムムタイヤによる接触皮周炎について IPPDA $0.1 \%$ 濃度の貼布試験で強陽性を示し, PPDA とも交差過敏性を示したことを報告している.PPDAは ゴム酸化防止剤として，今日では稀に使用されている程 度とされている ${ }^{10)}$. 本患者における貼布試験では, ゴム 製品自身と PPDA が陽性で，その他の酸化防止剤につ いては貼布試験を行なっていないので，原因物質の確定 にはな扮問題を残するのの，このような PPDA 類似構 造式を有する化学物質で交差反応を示す可能性が十分に 考えられる.MBT, TMTD の貼布試験か陰性であった ことからも，本症例の接触フレルゲンとして PPDA な いしその誘導体による可能性を重視したい，なお同時に 行なった数種類の重金属による貼布試験でる陽性反応が みられた。これらの重金属は必ずしも配合剤に含まれて いるとは限らない。これまでのゴム皮庙炎の報告で，配 合剂以外の物質による多価過敏性が報告されており5), 本症例も強くはないが，多価過敏性を示したといえよ 5 .

Melanodermatitis toxica（中毒性黑色皮庯炎）ないし occupational melanosis (職業性黒色症)といわれるも のは,どちらかといらとピッチ，アスファルト，クレオ ソート，鉱物油など、コールタール産物を取扱ら作業者 がその中に含まれる anthracene p phenanthrene の 光力学的作用によって, 顔面, 頸部などの露出部位にび 漫性の黑褐色色素沈着をきたすすので'11)，Riehl 黒皮症 とす密接な関保にある. 本症例の接触フレルゲンには光 線過敏性物質は含まれておらず，光線貼布試験で紫外線 照射によってとくに強く反応することはなく，また MED の低下るみられなかった。このことから，本症例 の色素沈着発生はゴムに含まれる接触フレルゲンが比較 的長期間接触されているらちに個体が感作され，あまり 強力ではないものの軽度の刺激が持続したため, 漸次, 表皮基底層の液状変性がおこって,メラニン顆粒が真皮 


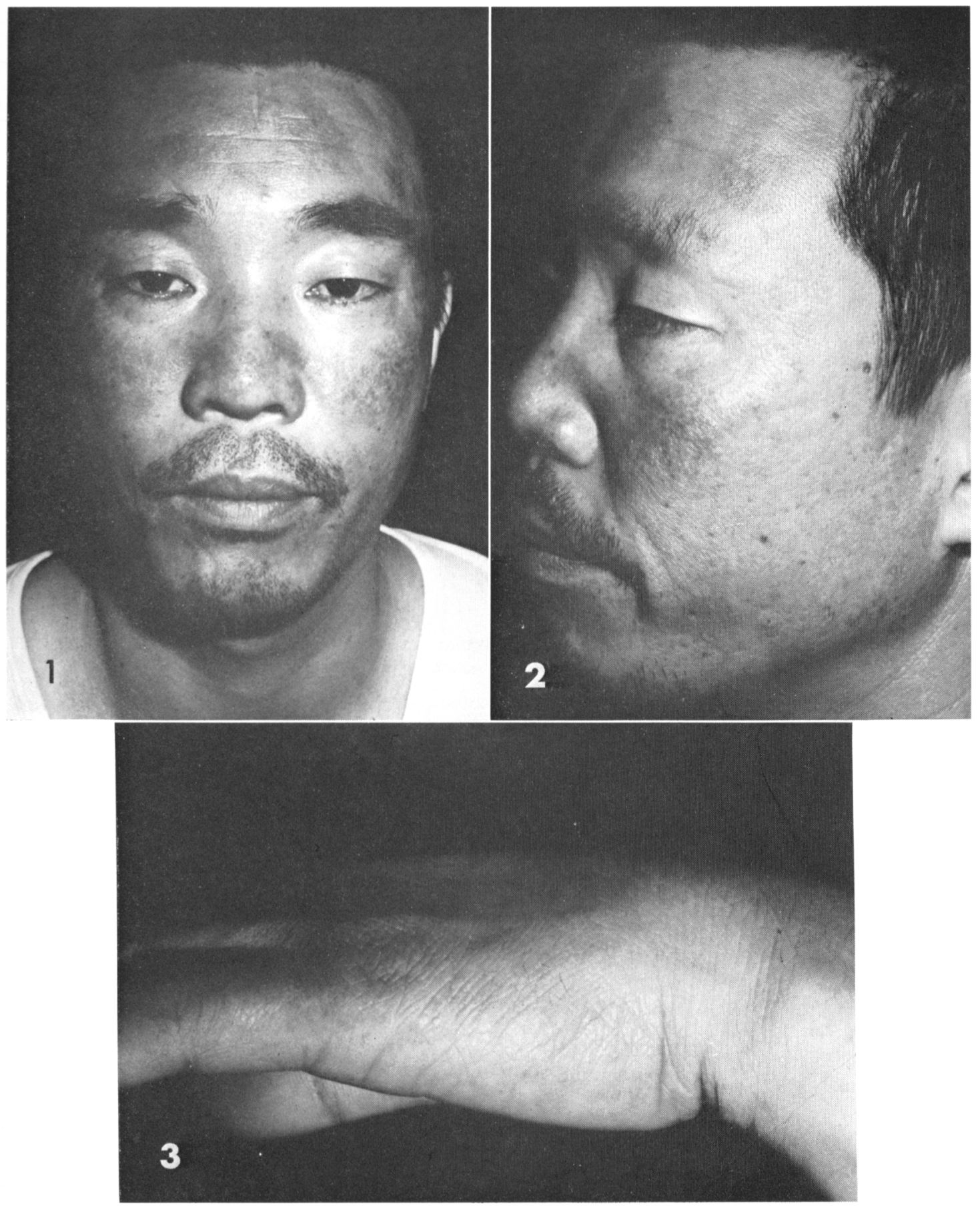

Fig. 1. Brownish black pigmentation on the periorbital regions of the face.

Fig. 2. The same patient as in Fig. 1. Pigmentation on the left lateral site of the face.

Fig. 3. Diffuse brownish black pigmentation on the lateral margin of the left hand. 

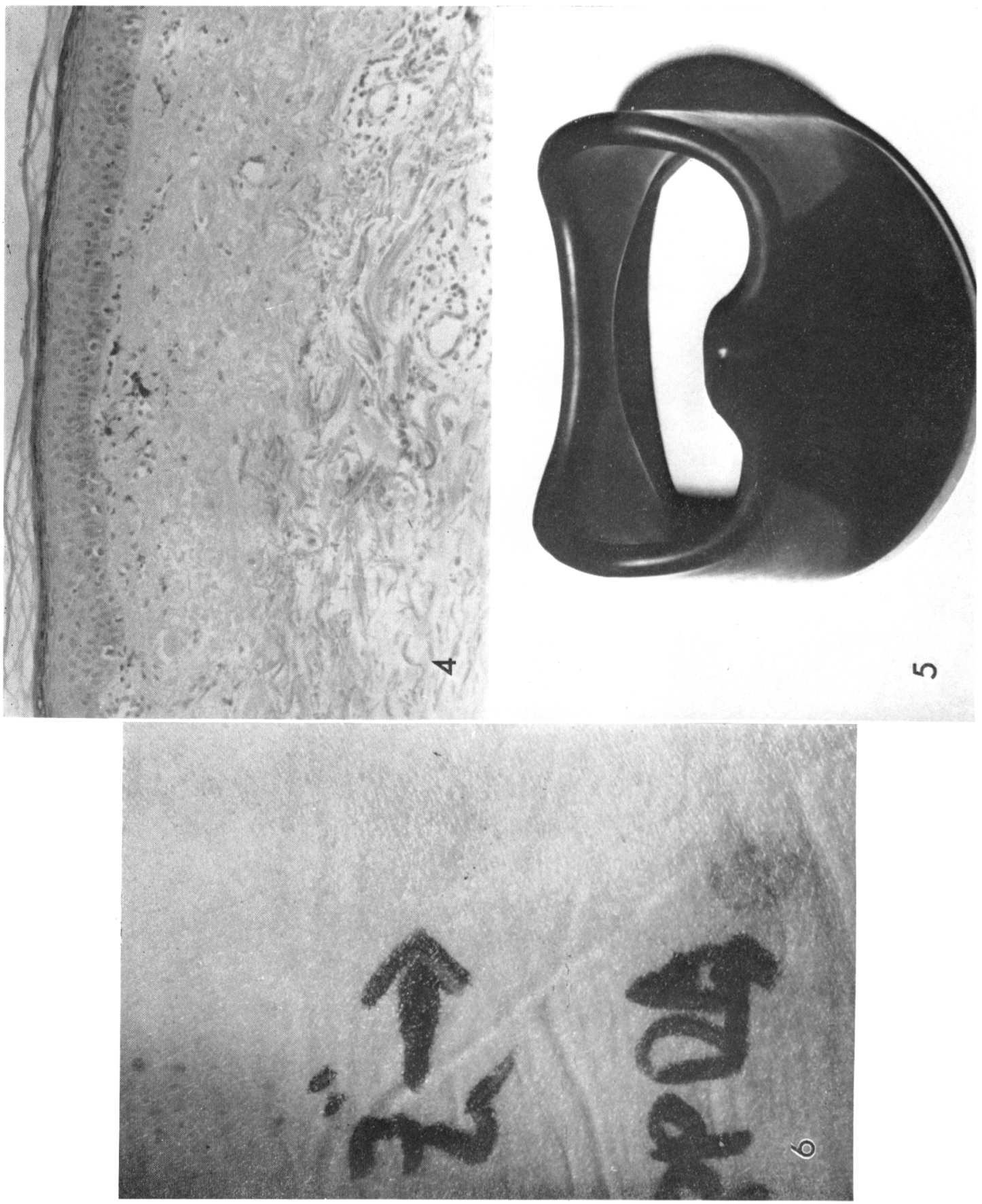

Fig. 4. Histological features of pigmented macules on the left cheek in Fig. 1, H. \& E. stain $(\times 310)$. Numerous melanophages in the upper dermis.

Fig. 5. Rubber covering around the peephole of a ship-radar-scope.

Fig. 6. View after closed patch tests for $48 \mathrm{hr}$. The rubber product (upper) and paraphenylenediamine (lower) showed positive results with papular eruptions. 
Table 1. A literature review of the occupational chronic melanodermatitis due to rubber products in Japan.

\begin{tabular}{|c|c|c|c|}
\hline Author (year) & $\begin{array}{l}\text { Circumstances causing } \\
\text { melanodermatitis }\end{array}$ & Cases & Symptoms and patch tests \\
\hline $\begin{array}{c}\text { Kobayashi \& } \text { Saika }^{3)} \\
\qquad(1955)\end{array}$ & $\begin{array}{l}\text { Workers using rubber product } \\
\text { of dust-respirator mask }\end{array}$ & 4 & $\begin{array}{l}\text { Violet brown pigmentation. Patch tests } \\
\text { by the rubber product and N-phenyl- } \beta \text { - } \\
\text { naphthylamine were all positive in } 4 \\
\text { cases. }\end{array}$ \\
\hline $\begin{array}{c}\text { Takeda } \text { et } \text { al. }{ }^{16)} \\
(1964)\end{array}$ & Workers in rubber factory & 4 & $\begin{array}{l}\text { Erythema, pigmentation and acne-like } \\
\text { eruptions on the face and forearms. } \\
\text { Patch tests with diphenylguanidin were } \\
\text { positive in } 4 \text { cases, those with tetrameth- } \\
\text { ylthiuram monosulphide were positive } \\
\text { in } 3 \text { cases and tests with N-phenyl- } \beta \text { - } \\
\text { naphthylamine, mercaptobenzoimidazole, } \\
4,4^{\prime} \text {-dihydroxy-diphenylcyclohexane were } \\
\text { weak positive in } 2 \text { cases. }\end{array}$ \\
\hline $\begin{array}{l}\text { Sato \& Takemura }{ }^{17)} \\
\text { (1965) }\end{array}$ & $\begin{array}{l}\text { Workers in manufacturing } \\
\text { factory of rubber-accelerators }\end{array}$ & 2 & $\begin{array}{l}\text { Pigmentation, follicular hyperkeratosis } \\
\text { and lichenoid papules on the face and } \\
\text { forearms. Patch tests with black resin } \\
\text { were positive in } 2 \text { cases and those } \\
\text { with N-phenyl- } \beta \text {-naphthylamine were } \\
\text { positive in one case. }\end{array}$ \\
\hline $\begin{array}{l}\text { Anzai et } \text { al. }^{18)} \\
\qquad(1967)\end{array}$ & $\begin{array}{l}\text { Workers planning the margin } \\
\text { of pressed rubber products }\end{array}$ & 1 & $\begin{array}{l}\text { Diffuse redness and violet black pig- } \\
\text { mentation. }\end{array}$ \\
\hline Nakasugi $^{19)} \quad(1970)$ & $\begin{array}{l}\text { Workers with chronic irrita- } \\
\text { tion by rubber-shielded elec- } \\
\text { tric wire in a mine }\end{array}$ & 1 & $\begin{array}{l}\text { Erythema and pigmentation, partly } \\
\text { depigmented spots on the cheeks. }\end{array}$ \\
\hline Hariu $^{20)} \quad(1970)$ & Workers in rubber factory & 1 & $\begin{array}{l}\text { Follicular hyperkeratosis and pigmenta- } \\
\text { tion on the forehead and the lateral } \\
\text { side of forearms. }\end{array}$ \\
\hline
\end{tabular}

に滴落し，真皮上層で macrophage に貪食され， melanophage として存在するためによるものと考えら れ, いわゆる炎症後の色素沈着に包含される. 光線アレ ルギー性接触皮膚炎の可能性は否定され得る.しかし患 部が顔面, 手などの露出部で, 職業柄, 日光照射を受け やすく, また組織像にて真皮の膠原線維が好塩基性変性 を示していたことからも, 紫外線照射がある程度, 色素 沈着に影響していることも考えられよう。

ゴム皮庙炎において, 本症例のごとき,び漫性の黒褐色 色素沈着を示す例は比較的少なく, 特定のアレルゲンが 色素沈着の原因とはいいにくいようである. 職業性のゴ ム皮后炎は本邦においてはそれほど多くないが12,13), 1949 年頃, 各地のゴム工場で多発し, 発赤, 毛孔性 色素沈着，痤瘡などをきたしたものはN-phenyl- $\beta$ naphthylamine が原因と考えられた ${ }^{14,15)}$. 本邦におけ
る職業性のゴムによる慢性黒色皮膚炎のこれまでの報告 例3,16 20) を一括して Table 1 に示す. 小林と雑賀 ${ }^{3)}$ は アレルゲンとして N-phenyl- $\beta$-naphthylamine をあげ, Takeda ら ${ }^{16)}$ は DPG, TS などの過敏性を指摘し，佐 藤と竹村 ${ }^{17)}$ は MBT 製造に際して生ずる副産物, いわゆ る black resin に過敏であったと述べている.これら以 外ではアレルゲンは明らかではない，自験例は接触アレ ルゲンとして PPDA ないしその誘導体による可能性が 強く示唆された。、いれにしてもこのよらな黒色皮膚炎 をきたすのは弱いフレルギー性刺激が比較的長期間持続 した場合に発生しており，そのうえに個体差や紫外線照 射なども関与するものと推測される.

\section{IV. 桔}

顔面および手に瘦痒を伴った特異な色素沈着をきた 
し, 精査の結果, 職業的に常時接触している船舶レーダ 一ののぞきロのゴムによる慢性黒色皮庙炎と判明した症 例について報告した. 症例は 40 歳の男子で, 瀬戸内海 航路フェリーボートの船長である. 顔面では眼窝部周囲 で, 前額, 頓骨部, 䫅部, 背部にかけて, 手ではその 外緑, 手背などに軽度の瘦痒とともに暗赤調を伴った黒 褐色の網状色素沈着をきたすようになった．頓部色素沈 着部皮疹の組織検査では真皮上層に血管周囲性のリンパ 球性細胞浸潤と多くのメラニン領食細胞がみられ, 炎症 による色素沈着の所見を示す. 本患者の皮庙におけるレ ーダーのぞきロのゴム製品の貼布試験では陽性を示し, またゴム酸化防止剤の中の代表的な paraphenylenediamine (PPDA) む陽性を示したが, ゴム加硫促進剤であ る mercaptobenzothiazole, tetramethylthiuram disulfide などでは陰性であった，以上のことからゴムによる 慢性接触性皮庙炎と考兄られた。 ゴム加工に使用される 酸化防止剤中には PPDA と類似構造式を示す物質が PPDA に交差陽性反応を示すことから，接触フレルゲン として PPDAないしその誘導体の可能性が重視された. な绝色素沈着を来たす機序として, 接触アレルゲンは余 り強力ではないが, 長期間それの接触が続いた場合, 表 皮基底層のメラニン顆粒が液状変性によって真皮に滴落 し, 真皮上層にメラニン領食細胞として強く残存した状 態を来たした結果と考えられる.併せて本邦におけるゴ ムによる慢性黒色皮膚炎報告例も紹介した。

本論文の要旨は昭和50年12月 4 日の第 15 回日本産業衛生学会 近畿地方会拉よび昭和 51 年 6 月 12 日の日本産業䚘生学会第 1 回 職業性フレルギー研究会において発表した.

\section{文献}

1) Fisher, A. A.: Contact Dermatitis, 2nd ed., 163-174, Lea \& Febiger, Philadelphia, 1973.

2) Adams, R. M.: Occupational Contact Dermatitis, 1st ed., 150-157, J.B. Lippincott Co., Philadelphia, 1969.

3）小林 浩, 雑賀晴彦: 防塵マスクによる皮庙障害, 労働
科学季報, $3: 59-63,1955$.

4) Wilson, H. T. H.: Rubber dermatitis. An investigation of 106 cases of contact dermatitis caused by rubber, Br. J. Dermatol., 81: 175-179, 1969.

5）斎藤文雄、山䔍淑枝：ヨム湿帘, 日皮会誌, 82：763$772,1972$.

6) Fregert, S.: Cross-sensitivity pattern of 2mercaptobenzothiazole (MBT), Acta Derm. Venereol., 49: 45-48, 1969.

7) Brand, P. H.: Ekzem durch Gummiprodukte, Dermatologica, 129: 440-445, 1964.

8) Gaul, L. E.: Paraphenylenediamine sensitivityPossible cross-sensitization to amine present in rubber, J. Invest. Dermatol., 34 : 255-258, 1960.

9) Schonning, L. and Hjorth, N.: Cross sensitization between hair dyes and rubber chemicals, Berufsdermatosen, 17: 100-106, 1969.

10) Jordan, W.P., Jr.: Contact dermatitis from N. isopropyl-N-phenylparaphenylenediame: “Volkswagen dermatitis," Arch. Dermatol., 103: 85-87, 1971.

11) Ebling, F. J. and Rook, A.: Disorders of skin colour, in Rook, A., Wilkinson, D.S. and Ebling, F. J. G., Eds., Textbook of Dermatology, Vol. II, 2nd ed., 1241-1288, Blackwell Scientific Publications, Oxford, 1972.

12）野村 茂：職業性皮店障害とその対策—労衝衛生管理 のために一，207-210, 労働科学研究所, 川崎, 1974.

13）永井隆吉：日本の職業性フレルギー性皮庙炎，皮膚科の 臨床, 18: 601--610, 1976.

14）久保田重孝, 野村 茂: 日本の職業性皮间障害, 260268 , 労働科学研究所出版部, 東京, 1953.

15）布施 玄：ゴム工の皮栭炎ならびに職業性座寉について， 皮闾と泌尿, 17: 516-517, 1955.

16) Takeda, K., Matsumoto, A. and Arakawa, T.: Four cases of erythromelanosis-Effects of compound in the rubber industries on the skin, Tokushima J. Exp. Med., 10: 223-230, 1964.

17）佐藤和三，竹村司：ゴム添加剤製造工場における Melanodermitis toxica 症例について, アレルギー, 14: 269, 1965.

18）安西 喬, 原田昭太郎, 岡部省吾: コムム作業者にみられ た Melanodermitis Toxica, 日皮会誌, 77: 392, 1967.

19）中杉 勇：坑内電灯線（ゴム製）の慢性刺戟による色素 沈着を伴なら接触皮虎炎，日皮会誌，80：52，1970.

20）針生敬三：ゴム工場従業員に見られた職業性皮風疾患, 日皮会誌, $80: 577,1970$.

著者への通信先 : 濱田稔夫， 干 545 大阪市阿倍野区旭町 1 丁目 5 番 7 号 大阪市立大学医学部皮 首科学教室 Reprint requests to Department of Dermatology, Osaka City University Medical School, 5-7, Asahimachi 1-chome, Abeno-ku, Osaka, 545 Japan (T. Hamada) 